\title{
Kinerja Jalan yang Dipengaruhi Parkir di Sepanjang Badan Jalan Sultan Thaha
}

\author{
1Fakhrul Rozi Yamali, ${ }^{2}$ Alfiansyah \\ ${ }^{1}$ Dosen Fakultas Teknik Sipil Universitas Batanghari \\ ${ }^{3}$ Mahasiswa Teknik Sipil Universitas Batanghari \\ Email: fakhrul_65@yahoo.co.id
}

\begin{abstract}
Abstrak. Penelitian ini bertujuan untuk mengetahui pengaruh parkir di badan jalan (on-street parking) di jalan Sultan Thaha Kota Jambi. Selain itu, juga untuk mengetahui besarnya penurunan tingkat kinerja jalan akibat kegiatan onstreet parking di jalan tersebut. Data yang dikumpulkan adalah survei lalu-lintas berupa survei arus lalu-lintas dan survei waktu tempuh kendaraan. Kondisi yang ditinjau dalam penelitian ini terdiri atas dua segmen. Segmen pertama adalah segmen jalan dengan kondisi jalan tanpa adanya kendaraan parkir dibadan jalan. Segmen kedua adalah bagian segmen jalan dengan kondisi terdapat kendaraan parkir diatas badan jalan. Hasil penelitian ini menunjukan bahwa terdapat pengaruh terhadap kinerja jalan dengan menganalisa kecepatan, volume dan kepadatan.
\end{abstract}

Kata Kunci : Arus Lalu-lintas, Parkir.

\section{PENDAHULUAN}

Dengan berkembangnya suatu kota akan menimbulkan peningkatan aktivitas masyarakat dan permintaan akan jasa transportasi semakin meningkat, sejalan dengan semakin tingginya arus lalu-lintas di suatu perkotaan. Bertambahnya sarana transportasi ini mengakibatkan volume lalu-lintas pada suatu jalan menjadi semakin besar. Masalah lain yang timbul, yaitu fasilitas parkir yang menggunakan badan jalan (onstreet parking). Parkir tersebut mengakibatkan lalu-lintas semakin tidak teratur, bahkan sering mengakibatkan terjadi tundaan.

Jalan Sultan Thaha merupakan salah satu jalan yang ramai dilalui di kota Jambi, jalan ini mempunyai letak strategis dan merupakan salah satu pusat perekonomian masyarakat, dikiri dan kanan jalan banyak berdiri bangunan seperti Pasar Los Angso Duo, Mall, Hotel, dan lain sebagainya, pada jam/hari tertentu volume kendaran meningkat dikarenakan banyak masyarakat melakukan proses jual beli disana, sehingga sebagian kendaraan parkir di badan jalan (on-street parking), dan membuat tundaan. Keadaan seperti ini cukup menganggu untuk saat ini serta bisa saja mengurangi kinerja dan kapasitas jalan ditahun kedepan.

\section{METODE PENELITIAN}

Dalam penelitian ini, survei dilakukan dengan mempergunakan peralatan sebagai berikut :

1. Formulir lembar isian survei, informasi umum harus diisi pada saat pelaksanaan survei, yaitu meliputi hari, tanggal, waktu pelaksanaan survei, kondisi cuaca, dan nama surveyor.

2. Peralatan yang harus dipersiapkan terlebih dahulu sekurang-kurangnya meliputi:

a. Papan alas (clip board) ukuran lebar $25 \mathrm{~cm}$ dan panjang $35 \mathrm{~cm}$ yang mempunyai penjepit pada bagian atasnya yang dipergunakan sebagai alas untuk menulis pada formulir survei.

b. Alat-alat tulis seperti kertas hvs, pena, pensil, dan penggaris.

c. Meteran dengan panjang 50 (lima puluh) meter, yang dipergunakan untuk mengukur geometrik jalan yang meliputi lebar kontruksi perkerasan jalan, lebar trotoar jalan serta mengukur panjang segmen jalan untuk data waktu tempuh kendaraan dan segmen panjang jalan untuk lokasi perhitungan volume kendaraan parkir.

d. Alat pengukur waktu (stop watch, jam tangan/hp) alat mengukur waktu dengan ketelitian 1/100 detik yang dipergunakan untuk mengukur waktu tempuh jenis atau kelompok kendaraan pada segmen jalan.

e. Arloji yang dipergunakan untuk menghitumg atau mengukur priode waktu pengumpulan data dengan interval waktu per 15 menit pada setiap waktu pengamatan jam sibuk pagi, siang, sore serta untuk mengetahui waktu kendaraan masuk dan waktu kendaraan keluar lokasi parkir.

f. Kamera sebagai alat untuk mendokumentasikan segala kegiatan dan kondisi di lapangan.

g. Counter tasbih digital, aplikasi dari hp, aplikasi ini berguna untuk menghitung kendaraan yang lewat. Data lain-lainnya yang dibutuhkan adalah: 
1. Data geometrik ruas jalan, yang meliputi panjang jalan, lebar perkerasan jalan, lebar jalur, lebar dan jumlah lajur lalu-lintas serta lebar trotoar jalan.

2. Data kelompok kendaraan dan volume setiap kelompok kendaraan pada setiap periode waktu pengamatan. Data ini dipergunakan untuk mengetahui volume maksimum atau arus lalu-lintas jam puncak pada setiap priode waktu pengamatan yaitu pada priode waktu jam puncak pagi, siang, dan sore hari.

3. Data waktu tempuh kendaraan untuk segmen ruas jalan dimulai STA.1000m+1050 atau sepanjang 50 meter dimana data ini dipergunakan untuk menghitung kecepatan rata-rata ruang (Us) dari arus lalu-lintas pada ruas jalan tersebut pada setiap priode waktu jam puncak pagi, siang, dan sore hari.

4. Data kendaraan roda empat yang masuk dan keluar lokasi parkir pada kedua sisi badan jalan dimulai STA.1000m+1200m atau sepanjang 200 meter. Data ini dipergunakan untuk menghitung dan melakukan analisa terhadap pengaruh kecepatan rata-rata ruang (Us) akibat berkurangnya lebar badan jalan efektif.

Data volume lalu-lintas dan waktu tempuh kendaraan tersebut dikelompokan menurut kelompok kendaraan yang terdiri atas :

1. Kelompok kendaraan ringan (KR) yang terdiri dari kendaraan bermotor roda 4 (empat).

2. Kelompok kendaraan berat $(\mathrm{KB})$ yang terdiri dari kendaraan bermotor roda 6 (enam).

3. Kelompok kendaraan sepeda motor (SMP) yaitu kendaraan bermotor beroda 2 (dua) atau beroda 3 (tiga).

Pelaksanaan pengumpulan data :

Sebelum pelaksanaan survei pengumpulan data yang sebenarnya, maka terlebih dahulu dilaksanakan observasi lapangan dan survei pendahuluan atau prasurvei. Observasi lapangan dilakukan untuk dapat menentukan lokasi survei yang paling tepat sebagai lokasi pengumpulan data dan lokasi studi.

Sebelum dilaksanakan survei pengumpulan data lalu-lintas terlebih dahulu ditentukan hari dan tanggal pelaksanaan survei yang dapat mewakili kondisi yang sebenarnya yang terjadi pada ruas jalan tersebut.

\section{Prosuder Penelitian}

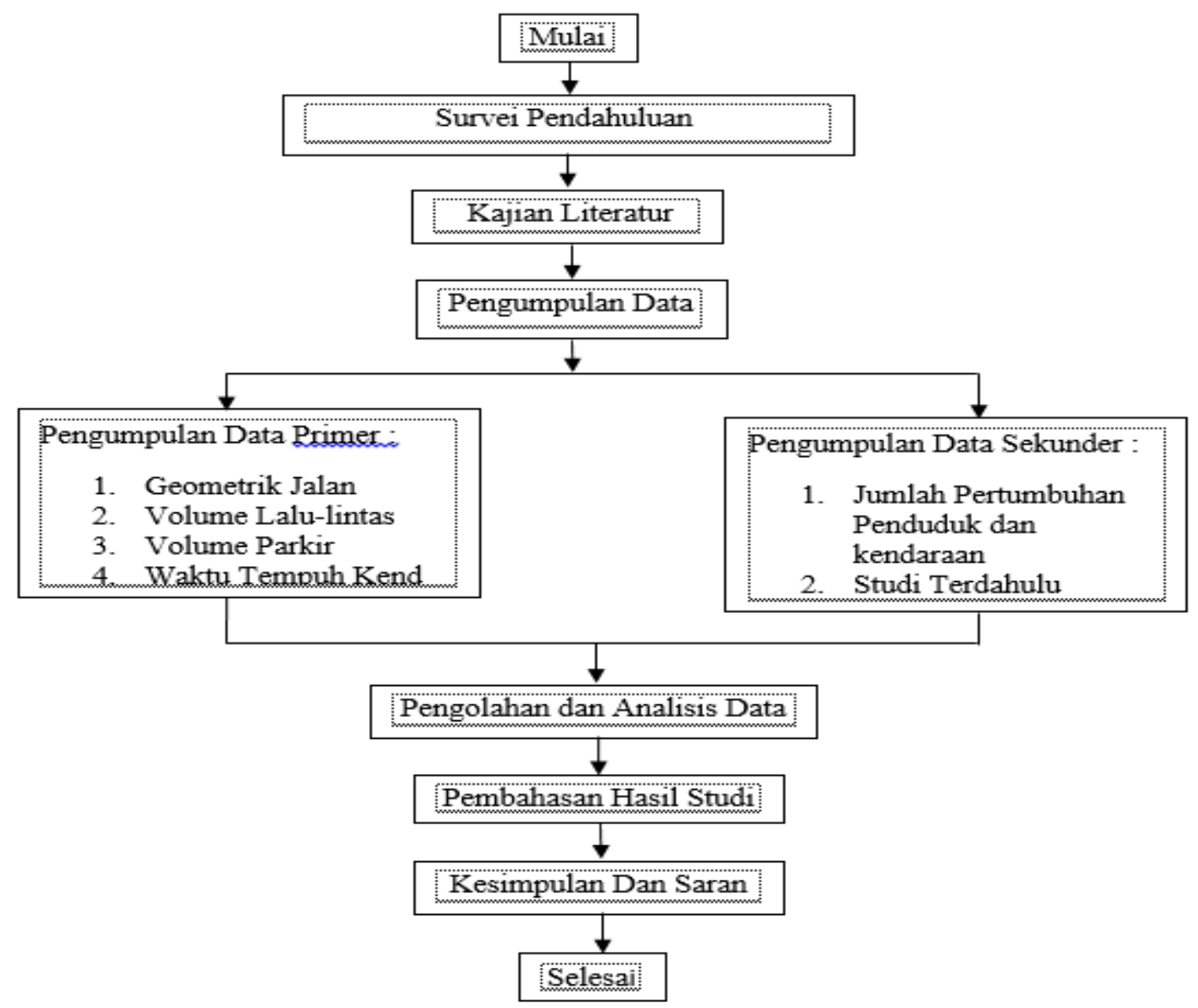

Gambar 1 :Flowchart

Sumber : Hasil Analisis, 2018 


\section{HASIL DAN PENELITIAN}

Ruas jalan Sultan Thaha kota jambi yang membentang dari arah utara ke selatan. Berdasarkan hasil pengukuran geometrik ruas jalan pada lokasi studi yang meliputi panjang jalan, lebar perkerasan jalan, lebar jalur lalu-lintas, lebar dan jumlah lajur lalu-lintas dan lebar saluran drainase, maka diperoleh hasil sebagai berikut :

Tabel 1 : Geometrik Ruas Jalan Sultan Thaha Kota Jambi

\begin{tabular}{|c|c|c|c|c|c|}
\hline \multirow[t]{2}{*}{ Nama Jalan } & \multirow{2}{*}{$\begin{array}{c}\text { Panjang } \\
\text { Jalan (Mtr) }\end{array}$} & \multicolumn{4}{|c|}{ Lebar Bagian Jalan (Meter) } \\
\hline & & Perkerasan & Lajur Lalu-lintas & Trotoar & Drainase \\
\hline Jl.Sultan Thaha & 1.300 & 17.85 & 11.15 & 1.30 & 1.00 \\
\hline
\end{tabular}

\section{Sumber : Hasil Pengukuran, 2018}

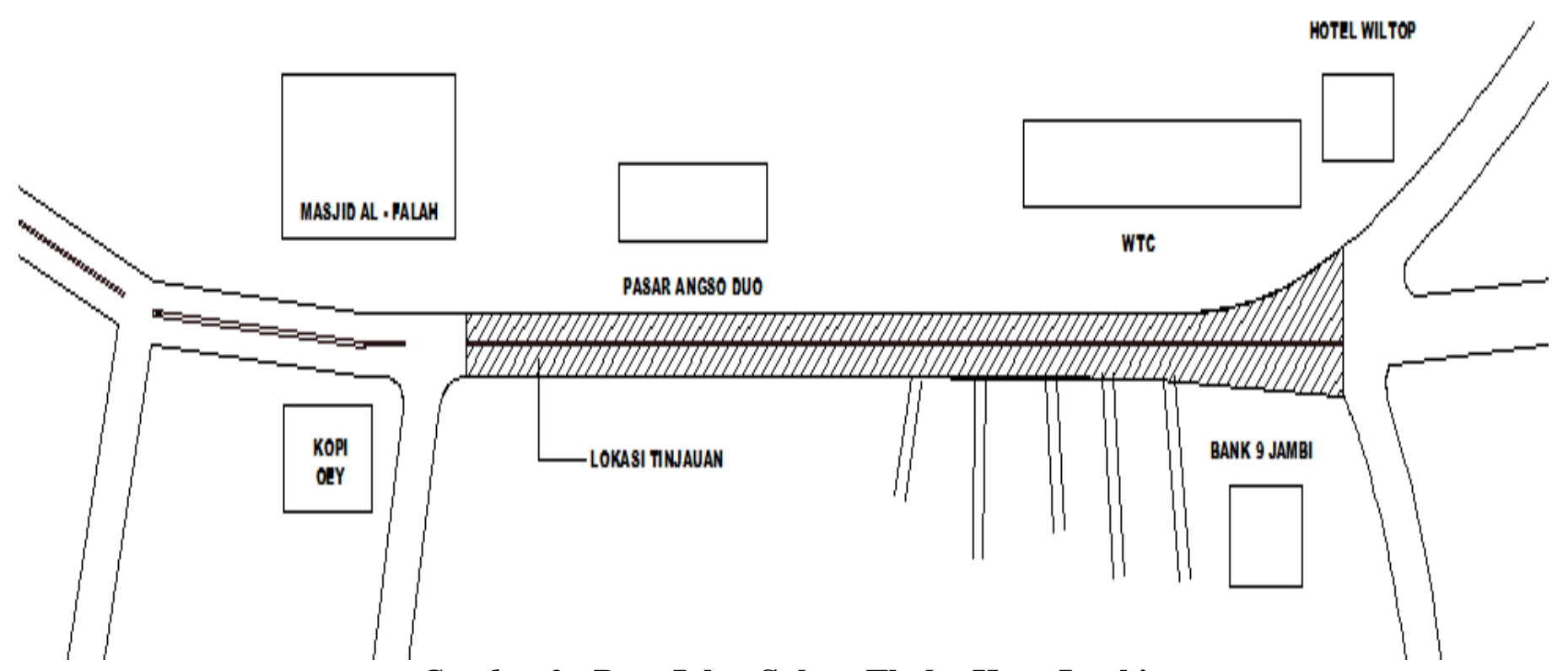

Gambar 2 : Peta Jalan Sultan Thaha Kota Jambi

Sumber : Hasil Survey di Lapangan, 2018

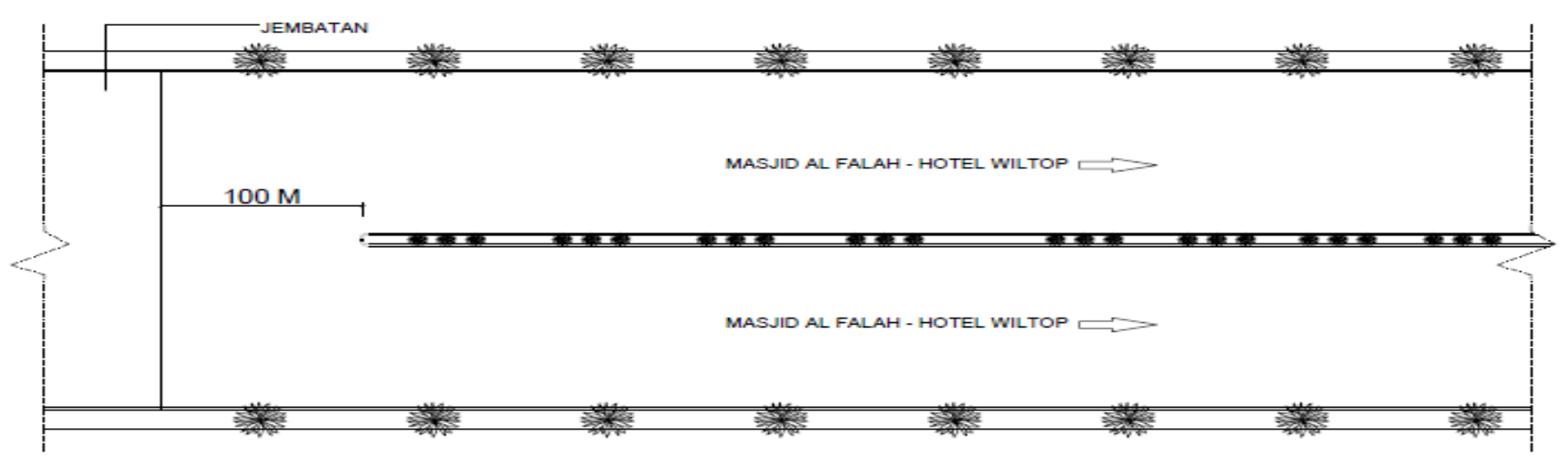

Gambar 3: Tampak Atas Ruas Jalan Depan Wiltop Trade Center (Wtc) Pada ruas Jalan Sultan Thaha

Sumber : Hasil Survey di Lapangan, 2018

\section{Volume Lalu-lintas}

Berdasarkan hasil survei yang telah dilaksanakan selama 3 (tiga) hari maka diambilah hari terpadat untuk volume lalu-lintas pada hari sabtu pada tanggal 12 januari 2019 selama 11 jam, dengan perhitungan setiap jenis atau kelompok kendaraan secara manual. Setelah dilakukan analisa serta perhitungan data hasil 
survey, maka didapat volume lalu-lintas untuk ruas jalan Sultan Thaha yang dibagi untuk setiap titik dan waktu pengamatan untuk setiap kelompok kendaraan.

Berdasarkan volume lalu-lintas hasil survey yang dihitung dalam satuan kendaraan per jam, selanjutnya ditentukan nilai faktor ekivalen mobil penumpang (faktor emp) menurut ketentuan dalam MKJI, 1997 yaitu sebagai berikut :

1. Sepeda Motor $(M C)$

2. Kendaraan Ringan $(L V)$

3. Kendaraan Berat $(H V)$

$$
\begin{aligned}
\text { emp } & =0,4 \\
\text { emp } & =1,0 \\
\text { emp }=1,3 &
\end{aligned}
$$

Selanjutnya berdasarkan volume lalu-lintas dalam satuan kendaraan per jam tersebut, dilakukan perhitungan dengan mempergunakan faktor emp untuk mendapatkan volume lalu-lintas dalam satuan smp/jam. Perhitungan volume lalu-lintas dari satuan kendaraan/jam menjadi satuan smp/jam dapat dilakukan dengan cara mengalikan volume hasil survey dengan faktor emp, sebagai mana contoh perhitungan dibawah ini yaitu untuk periode jam survey pada pukul 07.00 - 08.00 WIB, diperoleh hasil sebagai berikut :

Tabel 2 : Jumlah Smp/jam

\begin{tabular}{cccc}
\hline NO & Kendaraan & Jumlah kend x emp & Hasil Jumlah Smp/Jam \\
\hline 1 & Sepeda Motor & $1032 \times 0,4$ & 412 \\
2 & Kendaraan Ringan & $621 \times 1,0$ & 621 \\
4 & Kendaraan Truk & $2 \times 1,3$ & 2.6 \\
& Jumlah & 1655 & 1036 \\
\hline
\end{tabular}

Sumber : Hasil Analisa Data, 2019

\section{Tabel 3 : Volume Lalu-lintas Ruas Jalan Sultan Thaha 1 (satu) Arah}

\begin{tabular}{lccccc}
\hline & \multicolumn{2}{c}{ Jenis/kelompok dan jumlah kendaraan } & \multicolumn{2}{c}{ Volume Lalu-lintas } \\
Waktu Survey & Sepeda Motor & Kendaraan Ringan & Kendaraan Berat & Kend/Jam & Smp/Jam \\
\hline $07.00-08.00$ & 1032 & 621 & 2 & 1655 & 1036 \\
$08.00-09.00$ & 1453 & 802 & 8 & 2263 & 1394 \\
$09.00-10.00$ & 2366 & 1012 & 11 & 3389 & 1973 \\
$10.00-11.00$ & 2294 & 1216 & 10 & 3520 & 2147 \\
$11.00-12.00$ & 2345 & 1387 & 11 & 3743 & 2339 \\
$12.00-13.00$ & 2072 & 1112 & 44 & 3228 & 1998 \\
$13.00-14.00$ & 2223 & 1212 & 41 & 3476 & 2155 \\
$14.00-15.00$ & 2288 & 1239 & 25 & 3552 & 2187 \\
$15.00-16.00$ & 2013 & 1204 & 39 & 3256 & 2059 \\
$16.00-17.00$ & 2179 & 1291 & 23 & 3493 & 2193 \\
$17.00-18.00$ & 2293 & 680 & 37 & 3010 & 1645 \\
\hline
\end{tabular}

Sumber : Hasil Analisa Data, 2019

Bedasarkan hasil survey dan analisa data sebagaimana tabel tersebut dapat diketahui bahwa komposisi arus lalu-lintas jalan Sultan Thaha dimana kendaraan yang paling dominan adalah sepeda motor $(M C)$ dan kendaraan ringan $(L V)$, dimana perbandingan komposisi keempat kelompok kendaraan tersebut, rata-rata presentasenya adalah sebagai berikut :

$\frac{\text { Jumlah kendaraan }}{\text { Jumlah keseluruhan }} \times 100 \%$

1. Sepeda Motor $(M C)$

$$
=65,22 \%
$$

2. Kendaraan Ringan $(L V)=34,05 \%$

3. Kendaraan Besar $(H V)=0,73 \%$ 


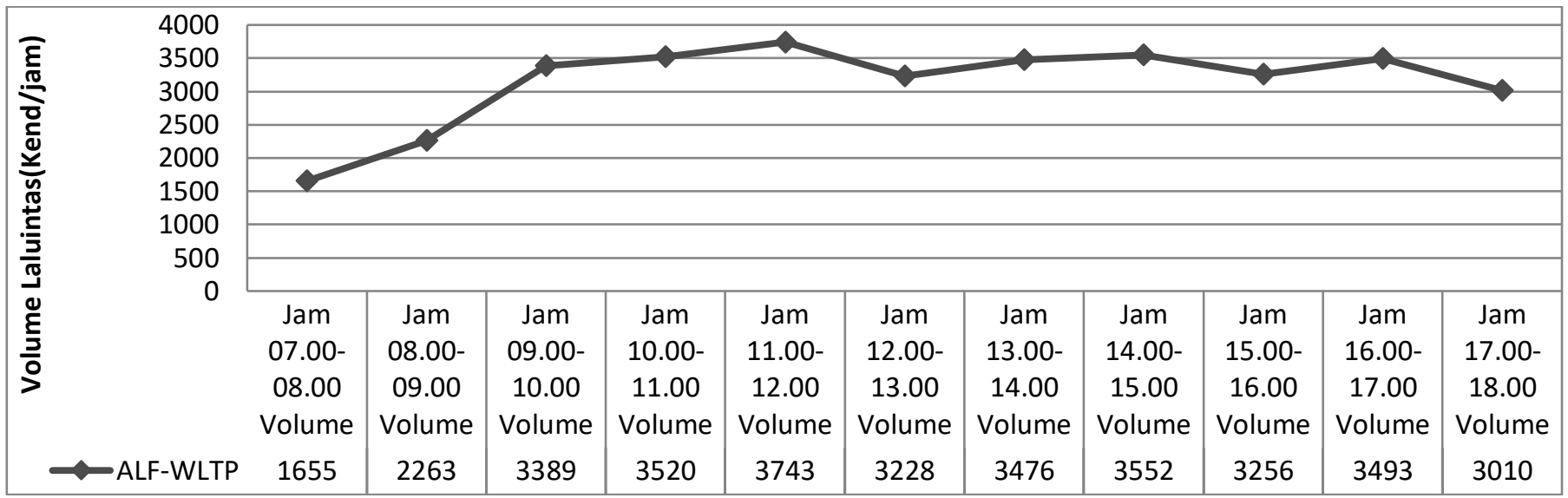

Gambar 4 : Grafik fluktuasi arus lalu-lintas dalam kend/jam

Sumber : Hasil Penelitian, 2019

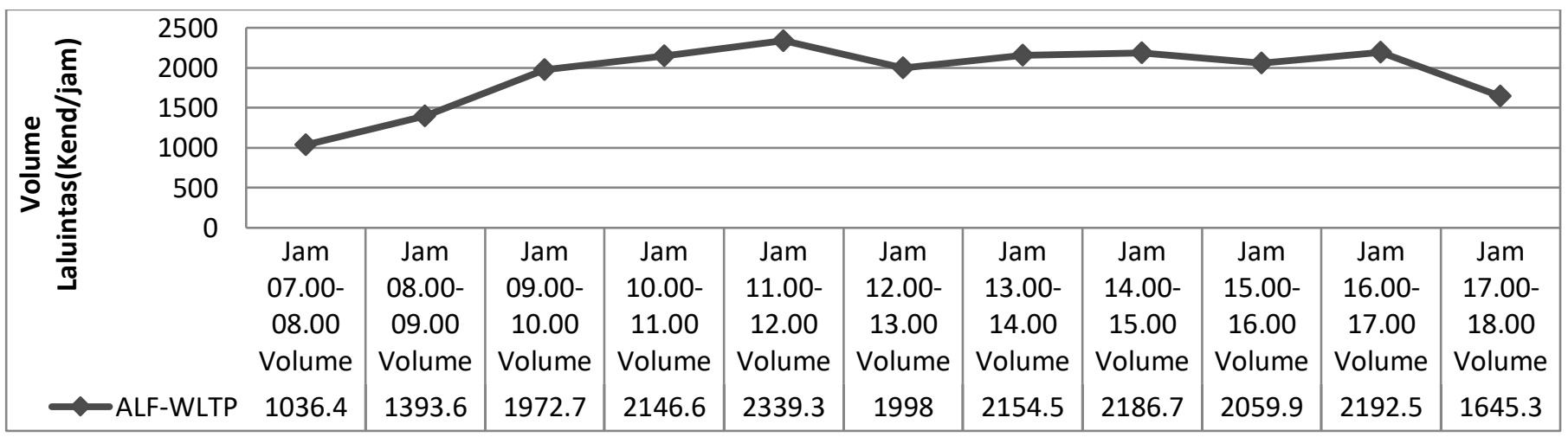

Gambar 5 : Grafik fluktuasi arus lalu-lintas dalam smp/jam

Sumber : Hasil Penelitian, 2019

Berdasarkan hasil pengukuran waktu tempuh untuk segmen panjang jalan 50 meter selama periode jam puncak pagi, siang dan sore hari, yang kemudian dilakukan perhitungan dengan menggunakan analisis Space Mean Speed atau kecepatan rata-rata ruang (Us).

Dimana :

$\mathbf{V}=\mathbf{S} / \mathbf{t}$

Keterangan :

$\mathrm{V}=$ kecepatan $(\mathrm{km} / \mathrm{jam})$

$\mathrm{S}=$ jarak $(\mathrm{km})$

$\mathrm{t}=$ waktu tempuh (jam)

Tabel 6 : Kecepatan Rata-rata Ruang (Us) Arus Lalu-lintas Diruas Jalan Sultan Thaha Pada Beberapa Jam Puncak

\begin{tabular}{lllcc}
\hline & & \multicolumn{3}{c}{ Kecepatan Rata-rata Ruang (Us) (Km/jam) } \\
\cline { 3 - 5 } Ruas Jalan & \multicolumn{1}{c}{ Arah Lalu-lintas } & Pagi & Siang & Sore \\
\hline Jalan Sultan Thaha & Masjid al-falah - Hotel wiltop & & & \\
& Minimum & 23 & 16 & 19 \\
& Maksimum & 38 & 23 & 29 \\
\hline
\end{tabular}

Sumber : Hasil Analisa Data, 2019

\section{Kecepatan Arus Lalu-lintas}

Berdasarkan hasil pengukuran waktu tempuh untuk segmen panjang jalan 50 meter selama periode jam puncak pagi siang dan sore hari, yang kemudian dilakukan perhitungan dengan menggunakan analisis Space Mean Speed atau kecepatan rata-rata ruang (Us), diperoleh sebagaimana berikut : 
Dengan hasil penelitian tabel diatas kecepatan rata-rata pada kecepatan kendaraan pada jam puncak pagi hari dapat mencapai $23 \mathrm{~s} / \mathrm{d} 38 \mathrm{~km} / \mathrm{jam}$, dan pada jam puncak siang hari dapat mencapai $16 \mathrm{~s} / \mathrm{d} 23$ $\mathrm{km} / \mathrm{jam}$, dan pada jam puncak sore hari dapat mencapai kecepatan 19 s/d 29 km/jam.

\section{Kepadatan Lalu-lintas}

Untuk menghitung kepadatan lalu-lintas yang terjadi pada ruas jalan Sultan Thaha, maka dihitung kepadatan lalu-lintas untuk total 1 (satu) arah, hal ini dikarenakan tipe jalan Sultan Thaha adalah 2/1. Selanjutnya hasil perhitungan kepadatan lalu-lintas adalah sebagai berikut menggunakan rumus di bawah :

$\mathbf{D}=\mathbf{Q} / \mathbf{U s}$

Keterangan :

$\mathrm{D}=$ jumlah kendaraan

$\mathrm{Q}=$ volume atau arus lalu-lintas (smp/jam)

Us $=$ kecepatan rata-rata ruang $(\mathrm{km} / \mathrm{jam})$

\section{Tabel 7 : Kepadatan Arus Lalu-lintas di Ruas Jalan Sultan Thaha Pada Beberapa Jam Puncak}

\begin{tabular}{lccc}
\hline \multicolumn{1}{c}{ Arah Lalu-lintas Total 1 Arah } & \multicolumn{3}{c}{ Kepadatan Lalu-lintas (smp/km) } \\
\cline { 2 - 4 } & Pagi & Siang & Sore \\
\hline Minimum & 10,36 & 19,98 & 16,45 \\
Maksium & 21,47 & 23,39 & 21,93 \\
\hline
\end{tabular}

Sumber : Hasil Analisa Data, 2019

Dari hasil perhitungan survei volume lalu-lintas pada jam puncak pagi, siang dan sore hari didapatkan hasil minimum dan maksimum yang dimana pada pagi hari kepadatan kendaraan tidak terlalu padat di bandingkan pada jam puncak siang hari.

\section{Parkir Kendaraan Pada Badan Jalan}

Penggunaan tepi jalan yaitu lajur paling pinggir disepanjang jalan Sultan Thaha dengan panjang segmen jalan yang diamati adalah sepanjang 200 M pada kedua sisi (kiri dan kanan) sebagai tempat parkir kendaraan roda 4 oleh setiap pengunjung Mall, Pasar, Tokoh dan Hotel di sepanjang jalan Sultan Thaha adalah sebagai berikut:

\begin{tabular}{lcccc}
\multirow{2}{*}{ Tabel 8 : Jumlah dan Lama Waktu Parkir Kendaraan Roda Empat Pada Tepi Jalan Sultan Thaha } \\
Pada Beberapa Jam Puncak
\end{tabular}

Sumber : Hasil Analisa Data, 2019

Dari tabel tersebut diatas diketahui bahwa jumah dan lamanya waktu parkir kendaraan roda 4 pada tepi jalan pada jam puncak pagi lebih kecil dibandingkan pada jam puncak siang, ataupun sore hari. Pada jam puncak sore hari diketahui bahwa jumlah kendaraan parkir pada tepi jalan semakin meningkat dan lamanya waktu parkir juga semakin bertambah, dimana hal tersebut juga menggambarkan meningkatnya berbagai aktivitas dan pergerakan masyarakat disekitar lokasi studi.

\section{Kinerja Ruas Jalan Pada Kondisi Saat Ini}

Kinerja ruas jalan dihitung berdasarkan metode Manual Kapasitas Jalan Indonesia MKJI, 1997 dimana parameter yang akan ditinjau adalah diantaranya adalah perbandingan (rasio) volume terhadap kapasitas (Q/C rasio) Kapasitas ruas jalan dihitung dengan persamaan : 
Dimana :

$\mathrm{C} \quad=$ Kapasitas dalam smp/jam

Co = Kapasitas dasar dalam smp/jam (Tabel C-1:1)

$\mathrm{FCw}=$ Faktor penyesuaian lebar jalur LL (Tabel C-2:1)

FCsp = Faktor penyesuaian pemisah arah (Tabel C-3:1)

FCsf = Faktor penyesuaian hambatan samping (Tabel C-4:1)

FCcs = Faktor penyesuaian ukuran kota (Tabel C-5:1)

Perhitungan kapasitas untuk ruas jalan Sultan Thaha sebagai tabel berikui ini :

Tabel 9 : Perhitungan Kapasitas ruas jalan

\begin{tabular}{cccccccc}
\hline $\begin{array}{c}\text { Co } \\
\text { Smp/Jam }\end{array}$ & FCw & FCsp & FCsf & FCcs & $\begin{array}{c}\text { C } \\
\text { Smp/jam }\end{array}$ & $\begin{array}{c}\text { Jumlah } \\
\text { Lajur Efektif }\end{array}$ & $\begin{array}{c}\text { C Total } \\
\text { smp/jam }\end{array}$ \\
\hline 1650 & 1,08 & 0,91 & 0,85 & 0,94 & 1296 & 2 & 2591,35 \\
\hline
\end{tabular}

Sumber : Hasil Penelitian, 2019

Dari tabel diatas diketahui bahwa kapasitas efektif untuk ruas jalaan Sultan Thaha adalah 2591,35 smp/jam, dengan demikian nilai Q/C rasio untuk lalu-lintas 1 (satu) arah dapat dihitung sebagai berikut :

1. Periode jam puncak pagi $\mathrm{Q} / \mathrm{C}=2147 / 2591,35=0,83$

2. Periode jam puncak siang $\mathrm{Q} / \mathrm{C}=2339 / 2591,35=0,90$

3. Periode jam puncak sore $\mathrm{Q} / \mathrm{C}=2192 / 2591,35=0,84$

Perameter selanjutnya yang harus dihitung untuk menentukan kinerja ruas jalan adalah kecepatan arus bebas, yaitu :

\section{FV $=($ Fvo + FVw $) \times$ FFVcs $(\mathbf{k m} / \mathbf{j a m})$}

$\mathrm{FV}=$ Kecepatan arus bebas kend ringan pad kend lapangan $(\mathrm{km} / \mathrm{jam})$

FVo $\quad=$ Kecepatan arus bebas dasar kend ringan (Tabel B-1:1)

$\mathrm{FVw} \quad=$ Penyesuaian kecepatan untuk lebar jalan (Tabel B-2:1)

FFVsf $\quad=$ Faktor penyesuaian untuk hambatan samping dan kereb (Tabel B-3:1)

FFVcs $\quad=$ Faktor penyesuaian untuk kota (Tabel B-4:1)

Tabel 10 : Perhitungan kecepatan arus bebas

\begin{tabular}{ccccc}
\hline Fvo Km/jam & FVw & FFVsf & FFVcs & FV Km/jam \\
\hline 57 & 4.00 & 0,85 & 0,95 & 49,26 \\
\hline
\end{tabular}

Sumber : Hasil Penelitian, 2019

Dari hasil perhitungan di atas diperoleh kecepatan arus bebas (FV) pada ruas jalan Sultan Thaha adalah 49,26 km/jam, dan kecepatan rata-rata ruang pada setiap jam puncak adalah:

1. Periode jam puncak pagi Us $=23-38 \mathrm{~km} / \mathrm{jam}$

2. Periode jam puncak siang Us $=16-23 \mathrm{~km} / \mathrm{jam}$

3. Periode jam puncak sore Us $=19-29 \mathrm{~km} / \mathrm{jam}$

Berdasarkan hasil analisa Q/C ration, kepadatan lalu-lintas, kecepatan rata-rata dan kecepatan arus bebas maka dapat ditentukan kinerja atau tingkat pelayanan jalan untuk ruas jalan Sultan Thaha saat ini yaitu untuk kondisi pagi dan sore hari "D" dan siang hari adalah "E".

Dimana :

"D” Arus mendekati tidak stabil, kecepatan masih dikendalikan, Q/C masih dapat ditolerir.

"E" Volume lalu-lintas mendekati atau macet berada pada kapasitas, arus tidak stabil dan kecepatan terkadang terhenti.

\section{Proyeksi Pertumbuhan Kendaraan}

Perhitungan pertumbuhan kendaraan di Kota Jambi diambil berdasarkan data jumlah kendaraan roda 2, dan roda 4 pada tahun 2013 - 2017. Data tersebut didapat dari Kantor Dinas Pendapatan Daerah Kota Jambi. Perhitungan pertumbuhan kendaraan di Kota Jambi dapat dilihat pada tabel berikut : 
Tabel 11 : Perhitungan kecepatan arus bebas

\begin{tabular}{ccccccc}
\hline No. & Tahun & $\begin{array}{c}\text { Roda 2 } \\
\text { MC }\end{array}$ & $\begin{array}{c}\text { Roda 4 } \\
\text { LV }\end{array}$ & Jumlah Kendaraan & $\%$ \\
\hline 1 & 2013 & 597420 & 139286 & 736706 & 0 & 0 \\
2 & 2014 & 638377 & 148116 & 786493 & 49787 & 6.8 \\
3 & 2015 & 669564 & 156395 & 825959 & 39466 & 5.0 \\
4 & 2016 & 694263 & 163705 & 857968 & 32009 & 3.9 \\
5 & 2017 & 725489 & 172984 & 898473 & 40505 & 4.7 \\
& & & & & 20.4 \\
\hline
\end{tabular}

Sumber : Data Olahan, 2019

Maka jumlah arus kendaraan untuk tahun 2021 sebagai berikut :

$\mathrm{Pn}=\mathrm{Po}^{*}(1+\mathrm{i})^{\wedge} \mathrm{n}$

Dimana :

Po = Jumlah volume lalu-lintas harian mula-mula

I = Tingkat pertumbuhan (rate of interest)

$\mathrm{n} \quad=$ Banyak waktu (dalam tahun)

$\mathrm{Pn} \quad=$ Jumlah volume lalu lintas pada akhir tahun ke-n

Volume kendaraan (MC) 2021

$2021=2366 \times(1+4 \%)^{\wedge} 3=2661$

Volume kendaraan (LV)

$2021=1387 \times(1+4 \%)^{\wedge} 3=1560$

Nilai DS pada tahun 2021 dapat dihitung menggunakan data arus yang sudah didapatkan yaitu $2661+1560$ $=4221 \mathrm{smp} / \mathrm{jam}$. Maka nilai derajat kejenuhan pada tahun 2021 adalah:

$\mathrm{Q} 2021=4221$

$\mathrm{Q} / \mathrm{C}(\mathrm{DS} 2021)=4221 / 2591,35=1.6($ Nilai Pelayanan F $)$

Nilai Pelayanan "F "Arus yang dipaksakan atau macet, kecepatan rendah, voume dibawah kapastitas, antrian panjang dan terjadi hambatan - hambatan yang besar"

\section{SIMPULAN}

1. Pada kecepatan kendaraan pada ruas jalan Sultan Thaha atau jalan kelas III B dengan tipe jalan kolektor sekunder dengan adanya kendaraan yang parkir pada badan jalan mengakibatkan pengaruh kecepatan kendaraan menurun sampai $16 \mathrm{~km} / \mathrm{jam} \mathrm{s} / \mathrm{d} 38 \mathrm{~km} / \mathrm{jam}$.

2. Berdasarkan hasil perhitungan derajat kejenuhan pada tahun 2019 dengan nilai puncak 0,9 dapat disimpulkan bahwa tingkat pelayanan jalan Sultan Thaha yaitu "E"(Volume lalu-lintas mendekati atau macet berada pada kapasitas, arus tidak stabil dan kecepatan terkadang terhenti) maka dengan hasil proyeksi 2021, nilai tingkat pelayanan derajat kejenuhan menjadi " $F$ "( Arus yang dipaksakan atau macet, kecepatan rendah, voume dibawah kapastitas, antrian panjang dan terjadi hambatan - hambatan yang besar) oleh karena itu, harus direncanakan solusi yang tepat untuk menghadapi kemacetan yang akan datang.

\section{DAFTAR PUSTAKA}

Abubakar Iskandar ,1996, Menuju Lalu-lintas dan Angkutan Jalan Yang Tertib, Ditjen Perhubungan Darat, Departemen Perhubungan RI : Jakarta.

C.Jotin Khisty \& Kent Lall ,2003, Dasar-dasar Rekayasa Transportasi Jilid 1 edisi ketiga. Erlangga : Jakarta.

Data Penduduk pada tahun, 2018 Badan Pusat Statistik (BPS) : Kota Jambi.

Data Pertumbuhan Kendaraan, 2013-2017 Dinas Pendapatan Daerah : Kota Jambi.

Keputusan Direktur Jendral Perhubungan Darat ,1996, Nomor :272/HK.105/DRJD/96

Tentang Pedoman Teknis Penyelenggaraan Fasilitas Parkir.

Ditjen Bina Marga Departemen Pekerjaan Umun RI, 1997, Manual Kapasitas Jalan Indonesia : Jakarta. 
Moch. Duddy Studyana, Yackob Astor, dan Irwan Susanto, 2012, Analisis Kapasitas Jalan Menggunakan Pendekatan Geospasial, Fakultas Teknik Sipil Politeknik : Bandung.

Direktorat Jendral Bina Marga, Direktorat Jendral Bina Jalan Kota. 1997, Manual Kapasitas Jalan Indonesia (MKJI).

Undan-undang Republik Indonesia NO.38 Pasal 1 Ayat 4 tahun 2004 Tentang Jalan Sekretariat Negara RI : Jakarta.

Peraturan Menteri Perhubungan Republik Indonesia No : 111, 2015, Tata Cara Penetapan Batas Kecepatan.

Sukirman,, 1994, Dasar-Dasar Perencanaan Geometrik Jalan Raya, Nova : Bandung

Supranto, 2000, Rumus Bunga Majemuk, Erlangga : Jakarta

Rancangan Standart Nasional Indonesia (RSNI), 2004, Geometri Jalan Perkotaan.

Sakti Adji, 2011, Perencanaan Pembangunan Transportasi Jalan Umum, Graha Ilmu : Yogyakarta. 